\title{
Pilar-Pilar Eksistensi Dan Keberlanjutan Kampung Kramat: Kampung Tematik Di Tpu Kasin Kota Malang
}

\author{
Antonio Heltra Pradana \\ Departement Teknik Arsitektur dan Perencanaan, Magister Perencanaan Wilayah Kota, Universitas Gadjah Mada \\ *antonio.heltra.p@mail.ugm.ac.id
}

INFO ARTIKEL

Riwayat Artikel:

Diterima: 04-07-2019

Disetujui: 16-11-2019

\section{Kata Kunci:}

Pilar-pilar eksistensi; Kampung Kramat; Kampung tematik; Kesejarahan: Ketokohan;

Generasi

\section{ABSTRAK}

Abstrak: Di Kota Malang terdapat kampung tematik di TPU Kasin yaitu kampung Kramat. Kampung ini telah ada sejak 50 tahun lalu dan dulu dikenal sebagai kampung pelarian. Tujuan dari penelitian ini adalah untuk mencari tahu tentang pola kehidupan social masyarakat Kampung Kramat, dengan mendalami hal-hal terkait cara masyarakat kampung Kramat bertahan hidup ditengah-tengah lingkungan pemakaman, pola hubungan antara masyarakat yang satu dengan yang lain di Kampung Kramat, proses transformasi Kampung Kramat dari Kampung pelarian menjadi Kampung tematik dan basis keberadaan dan keberlanjutan Kampung Kramat. Metode yang digunakan dalam penelitian ini adalah deksriptif-induktif-kualitatif dengan pendekatan fenomenologi. Pendekatan ini digunakan untuk menggali konsep warga Kampung Kramat bertahan hidup dan cara mereka mempertahankan kampungnya hingga sekarang menjadi kampung tematik. Hasilnya, kampung dapat bertahan keberadaannya karena memiliki konsep meruang-berkehidupan yang kontekstual-kompleks. Konsep-konsep ini menjadi pilar-pilar penyokong keberadaan dan keberlanjutan Kampung Kramat. Adanya studi ini diharapkan dapat menjadi pertimbangan khusus mengenai arahan pemberdayaan kampung kota melalui konsep tematik agar dapat lebih mengena dan berdaya guna. Khususnya bagi kampung yang terletak di area pemakaman.

Abstract: In Malang regency, there is a thematic village in TPU Kasin namely Kramat Village. This village has existed since 50 years ago and was once known as an escape village. The purpose of this research is to find out about the social life pattern of the people of Kampung Kramat, by exploring the things related to the way the village of Kramat survive amid the funeral environment, the pattern of relationship between Community that is one with the other in Kampung Kramat, the transformation process of Kampung Kramat from the runaway village becomes the thematic village and base of the existence and sustainability of Kampung Kramat. The method used in this research is a-inductive-qualitative dexsriptif with a phenomenological approach. This approach is used to excavate the concept of villagers survive and the way they defend their village is now a thematic village. As a result, the village can survive its existence because it has a contextual-complex living concept. These concepts are the pillars of the existence and sustainability of Kampung Kramat. The existence of this study is expected to be a specific consideration of the direction of empowerment of village city through thematic concept to be more effective and effective. Especially for the village located in the burial area. 


\section{A. LATAR BELAKANG}

Kampung Kramat adalah satu dari beberapa kampung tematik yang berada di Kota Malang. Kampung ini direalisasikan menjadi kampung tematik setelah memenangkan juara ketiga lomba Rancang Malang pada tahun 2016. Sebelum menjadi kampung tematik, kampung ini adalah kampung kumuh yang sering menjadi langganan banjir dan lebih dikenal pada awal berdirinya sebagai kampung pelarian. Kampung ini sempat menjadi viral karena keunikannya sebagai kampung tematik yang berada di tengah pemakaman [1].

Adanya kampung dan pemakaman yang berada di satu tempat yang sama ini menarik Peneliti untuk mendalami relasinya dengan lingkungan sekitar. Bagaimana mereka dapat bertahan hidup di tengah lingkungan pemakaman? Bagaimana mereka dapat memperta-hankan kampungnya bertahun-tahun walau berada di tanah TPU? Bagaimana relasi sosial dan aktivitas kehidupan warga di sana? Bagaimana proses kampung berubah dari kampung pelarian menjadi kampung tematik? Apa yang menjadi basis keberadaan dan keberlanjutan kampung Kramat ini? Beberapa pertanyaan ini membuat kampung yang terletak di atas TPU Kasin ini menarik untuk diteliti.

\section{B. METODE PENELITIAN}

\section{Telaah Teoritik}

Ruang sebagai wadah kehidupan manusia memiliki dimensi sejarah yang terkandung di dalamnya. Sejarah yang terkandung dalam ruang tersebut dapat dilacak melalui-memori-memori manusia tersebut [2]. Dalam perspektif ini, dapat dipahami bahwa ruang secara utuh merupakan pengejawantahan dari koleksi memori dan kesadaran subjektif setiap individu yang pada dasarnya selalu terhubung dengan memori-memori yang lalu beserta segala pengalaman ruangnya.

Heidegger dalam Lefebvre [3] mengatakan bahwa "Dwelling is the basic character of being in keeping with which mortals exist". Yang artinya, berhuni merupakan karakter manusia sebagai makhluk yang berusaha "mengada" di dalam keberadaan dunia secara utuh.

Dalam kerangka pikir ini, maka kampung dapat dipahami sebagai lokus berhuni manusia perkotaan dalam kesatuannya dengan seluruh aktivitas perkotaan. Di dalam ruang tersebut manusia kampung tersebut berusaha "mengada" dan mengejawantahkan dirinya dalam aktivitas berhuni dengan segala kebisaan dan keterbatasannya. Aktivitas "mengada-berada-ada" di kampung ini tentunya berbeda seturut setting ruang yang berbeda. Kebutuhan mengejawantahkan dalam ruang kampung pada akhirnya menunjukkan bahwa kampung sebagai ruang (space) juga memiliki konsep kesadaran tertentu karena aktivitas meruang masyarakatnya dengan seluruh relasi dengan lingkungan disekitarnya [4].

\section{Metode penelitian}

Penelitian ini bersifat deskriptif-induktif-kualitatif dengan menggunakan pendekatan fenomenologi. Pilihan pendekatan ini digunakan karena dirasa paling tepat untuk menggali keunikan dari fenomena kampung yang terletak di atas TPU Kasin ini.

Teknik pengumpulan informasi dilakukan dengan wawancara mendalam serta observasi intensif di lingkungan kampung Kramat. Untuk mendapatkan informasi yang akurat dan valid, penelitian ini menggunakan teknik triangulasi dan teknik wawancara berulang. Kedalaman informasi yang digali didapatkan dari perulangan-perulangan wawancara serta observasi teliti terhadap keunikan yang ditemukan di kampung Kramat.

Setelah terkumpul informasi hingga jenuh, analisa dilakukan dengan menggunakan teknik induksi. Proses induksi ini menggunakan empat tahapan. Tahap pertama adalah penggalian unit-unit informasi dari narasumber terpilih dan observasi lapangan. Tahap berikutnya adalah pengelompokan unit-unit informasi dalam tema-tema. Setelah terbentuk tema-tema, tahap berikutnya adalah memeras tema-tema tersebut menjadi konsep-konsep mengenai kampung Kramat. Pada tahapan terakhir, konsep-konsep tersebut diperas lagi untuk mendapatkan abstraksi konsep dari keberadaan dan keberlanjutan kampung Kramat.

\section{Lokasi Penelitian}

Penelitian berlokasi di TPU Kasin, Kelurahan Kasin, Kota Malang. Kampung ini ada dalam administrasi RT o7 RW 03, Kelurahan Kasin, Kota Malang. Kampung Kramat terletak di sisi barat daya TPU Kasin dan berbatasan langsung dengan sungai Kasin. Kampung ini terdiri dari $65 \mathrm{KK}$ dan 61 rumah yang terbentuk selama empat generasi. Lokasi kampong Kramat dapat dilihat pada gambar 1.

Dalam lingkup skala kota, TPU Kasin berada dekat dengan pusat Kota Malang. Kawasan di sekitar TPU Kasin ini tergolong ramai dan telah tumbuh berkembang sejak sebelum kemerdekaan oleh pemerintah kolonial Belanda [5][6]. Sekarang kawasan ini menjadi salah satu penyokong kawasan pusat kota Malang, dapat dilihat pada gambar 2 .

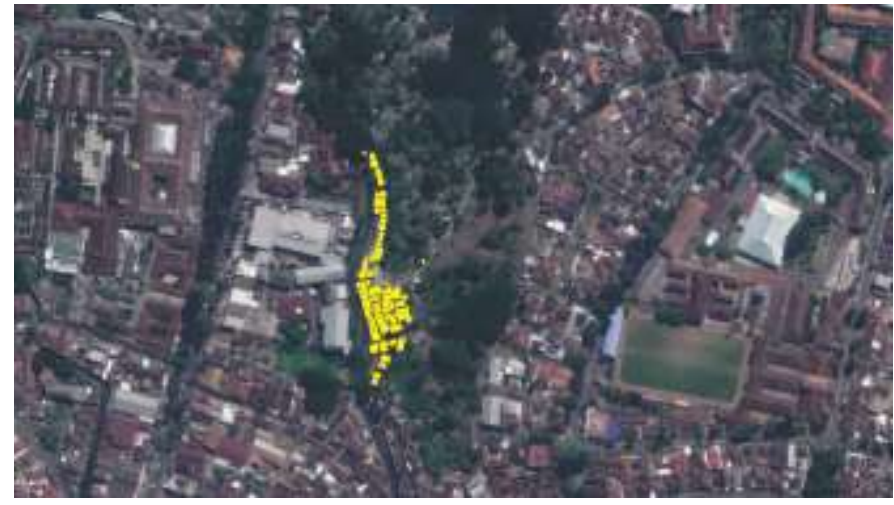

Gambar 1. Lokasi kampung Kramat di TPU Kasin, Kota Malang 


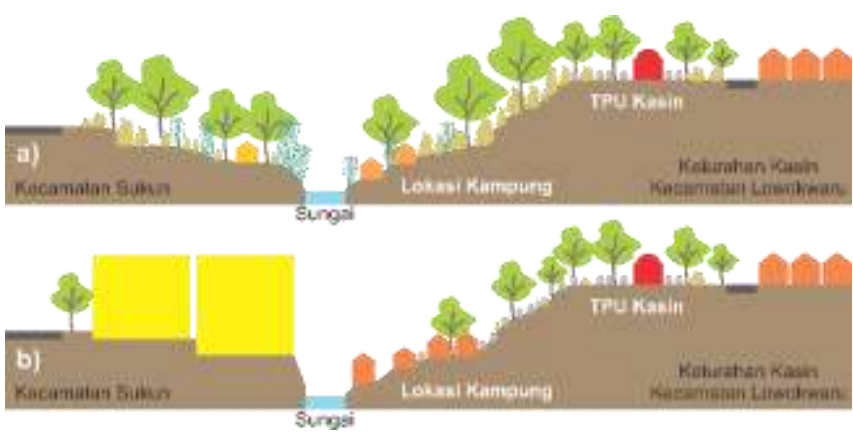

Gambar 2. Potongan kawasan Kampung Kramat a) dulu, b) sekarang

\section{HASIL DAN PEMBAHASAN}

Dari hasil wawancara mendalam, observasi dan pengumpulan unit-unit informasi, dikelompokkanlah informasi tersebut menjadi 19 tema. Tema-tema tersebut adalah (1) Sejarah ruang di sekitar TPU Kasin, (2) Sejarah TPU Kasin, (3) Sejarah Kampung Kramat, (4) Lokasi strategis Kampung Kramat, (5) Tokoh-tokoh di Kampung Kramat, (6) Peran lembaga dan bantuan keagamaan di kampung, (7) Langgar dan Gereja di dalam kampung, (8) Status kepemilikan lahan dan rumah, (9) Ikatan keluarga warga kampung, (10) Permasalahan ruang di kampung, (11) Adaptasi hunian warga kampung, (12) Mata pencaharian warga kampung, (13) Ruang aktivitas warga kampung, (14) Perkembangan infrastruktur kampung, (15) Tradisi haul, Jumat Legian dan hari besar keagamaan Islam, (16) Lomba kampung tematik dan peran pihak luar, (17) Hubungan sosial warga, (18) Persepsi warga kampung tentang kampungnya, (19) Peran pemerintah dan pemilu.

Kesembilan belas tema ini saling berhubungan satu dengan lainnya sehingga terbentuklah tiga konsep yang menjadi basis keberadaan dan keberlanjutan kampung ini. Ketiga konsep ini adalah (1) Pemanfaatan jejaring eksternal warga kampung, (2) Pergeseran kampung pelarian menjadi kampung umum, (3) Pelapisan generasi dalam memaknai kampung. Konsep konsep ini kemudian diabstraksi menjadi pilar-pilar keberadaan dan keberlanjutan Kampung Kramat. Alur induksi tema tersebut dapat dilihat pada gambar 3 .

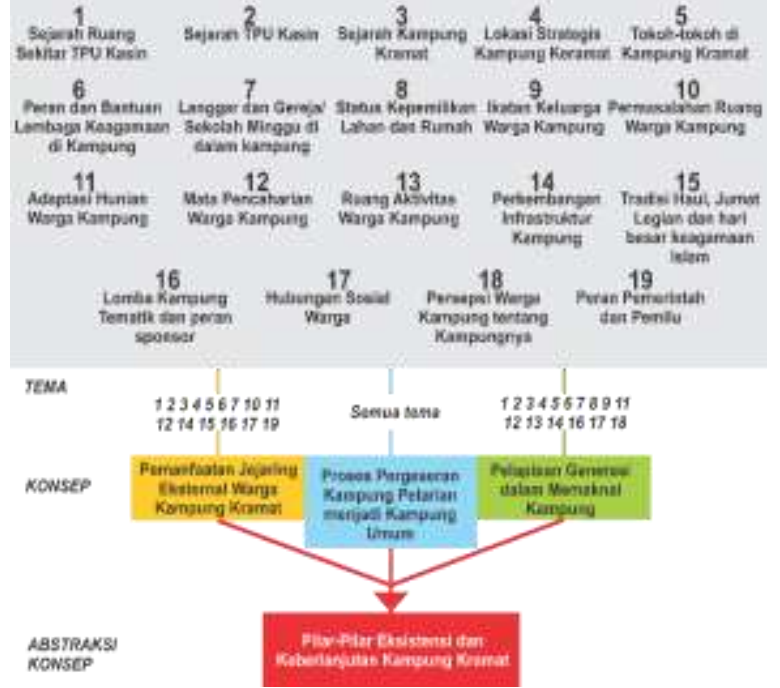

Gambar 3. Alur induksi tema menuju abstraksi konsep

Dari alur tersebut berikut dipaparkan ringkasan singkat mengenai hasil tema-tema yang telah dikelompokkan. Tema-tema ini membentuk informasi holistik utuh mengenai keberadaan Kampung Kramat dan sejarah perjalanan personal-komunal serta lingkungan fisik kampung. Untuk lebih memperjelas konteks kampung Kramat dalam perjalanan waktu, berikut adalah linimasa perjalanannya dari awal kampung didirikan hingga menjadi kampung tematik. Transformasi kampong kramat dapat dilihat pada gambar 4

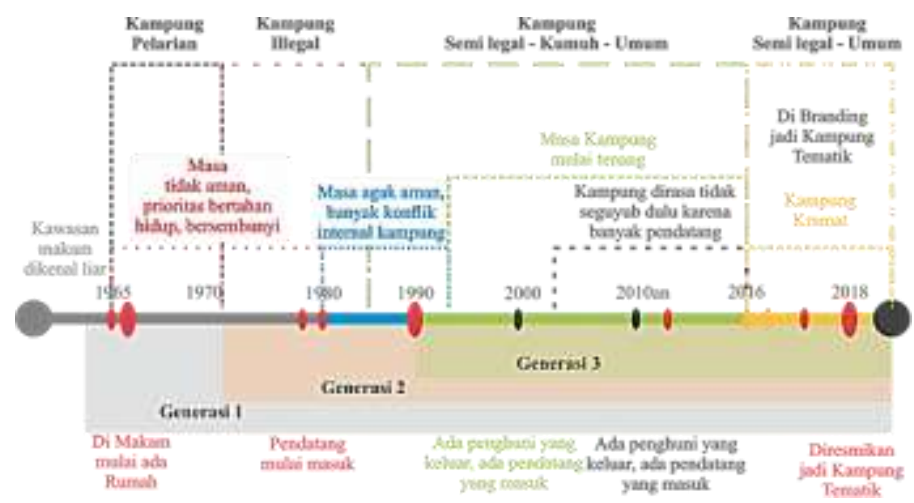

Gambar 4. Linimasa peristiwa perjalanan Kampung Kramat

Sejak kampung mulai ada memang sudah banyak aktivitas keluar masuk yang terjadi di kampung dan makam. Perkembangan kawasan Kasin yang terjadi sejak zaman pemerintahan kolonial Belanda membuat kawasan ini amat dinamis. Adanya peristiwa politiksosial-ekonomi di kawasan ini juga berimbas lingkungan makam yang kemudian tumbuh berkembang hingga menjadi Kampung Kramat saat ini [6].

Berdasarkan informasi yang didapat dari wawancara dengan warga di sekitar TPU Kasin, kampung ini mulai terbentuk sekitar dekade 1960. Menurut mereka, Kampung Kramat awalnya adalah tempat pelarian masyarakat yang memiliki berbagai permasalahan. Ada yang memiliki persoalan ekonomi sehingga melarikan diri dan ada pula yang memiliki masalah sosial maupun karena tersangkut peristiwa 
tahun 1965. Karena persoalan tersebut mereka mencari tempat aman dengan bersembunyi dan tinggal di pemakaman.

Menurut warga yang tinggal pertama di pemakaman, kampung ini merupakan tempat yang strategis. Hal ini karena kawasan TPU Kasin dikelilingi banyak fasilitas penting seperti Pasar Comboran, Pasar Besar, beberapa rumah sakit, sekolah, dan banyak rumah ibadat. Selain itu kawasan ini juga banyak dilalui kendaraan umum dari berbagai sudut Kota Malang sehingga warga dengan mudah dapat pergi ke berbagai tempat. Kondisi ini juga membuat warga luar yang turut tinggal di kampung Kramat (karena menikah dengan warga asli) menjadi betah tinggal di kampung.

Dalam perjalanannya, berbagai konflik dan dinamika terjadi silih berganti di kampung. Mulai dari konflik dengan preman-preman di pemakaman karena ada warga kampung yang diperkosa, konflik lahan dengan TPU terkait penambahan rumah tinggal, ancaman penggusuran, hingga konflik internal karena perbedaan agama antar warga. Pasang surut relasi dalam bertetangga terjadi sejak perjalanan kampung ini dimulai

Dapat dibayangkan pada awal-awal tinggal di pemakaman, sama sekali tidak ada infrastruktur dan kondisi kampung amat jauh dari kata layak. Namun seiring berjalannya waktu, warga melalui tokohtokohnya terus menerus berusaha memperbaiki taraf kehidupan dan kondisi fisik kampungnya. Dalam hal infrastruktur mereka melakukan perbaikan dan pembangunan jalan setapak, pemasangan dan saluran listrik, pembuatan drainase dan pemasangan jalur PDAM. Tidak jarang juga tokoh-tokoh tersebut berperan penting mengakses bantuan vital infrastruktur kampung, seperti pembangunan menjadi kampung tematik. Sedangkan dalam hal penghidupan keseharian, bantuan yang diakses tokoh-tokoh kampung tersebut meliputi pendidikan, kesehatan, dan kebutuhan sembako. Bantuan dari berbagai pihak tersebut mereka gunakan untuk kesejahteraan warga seluruhnya dengan tujuan untuk tetap bertahan hidup.

Sejak didirikan, berbagai cara warga gunakan untuk dapat hidup secara layak. Mulai dari mengakses berbagai bantuan untuk infrastruktur hingga biaya hidup sehari-hari. Bantuan dari lembaga keagamaan menjadi salah satu penyokong utama keberlangsungan kehidupan kampung ini. Terutama bantuan dari lembaga Kristen dan Katolik. Bahkan warga memiliki strategi ikut agama pemberi bantuan agar mendapat jatah (walaupun mayoritas warga kampung beragama Islam). Kendati persoalan dan himpitan ekonomi masih menjadi permasalahan hingga saat ini, warga tetap dapat merasakan kehidupan mendekati standar layak karena bantuan-bantuan tersebut. Potret kondisi permukiman kampong Kramat saat ini dapat dilihat pada gambar 5 .
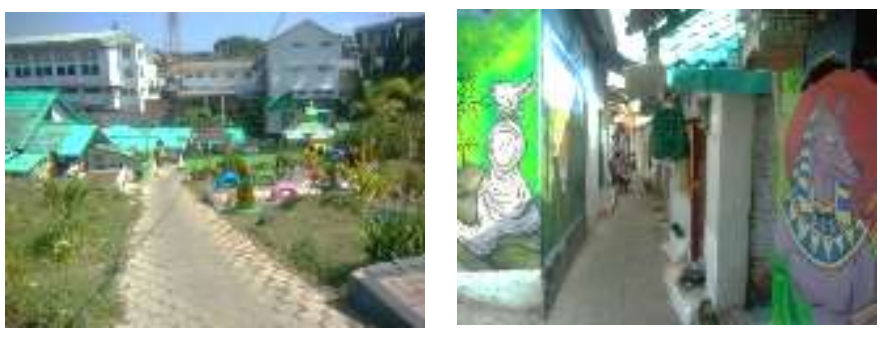

Gambar 5. Foto Kampung Kramat saat ini

Mengenai status kepemilikan rumah dan tanah, warga sebetulnya menyadari bahwa mereka hanya menumpang di tanah makam. Berbagai konflik yang dialami di pemakaman membuat mereka sempat terancam digusur dan direlokasi. Oleh karena itu, mereka memiliki prinsip bahwa harus bersikap baik dengan pihak TPU dan tidak menambah hunian lagi yang dapat mengurangi luasan tanah makam. Mereka juga berusaha menghindari konflik dengan pihak TPU agar masih tetap diizinkan tinggal.

Hal unik lain yang dijumpai di kampung ini adalah adanya gereja (sekarang disebut sekolah minggu) dan langgar yang dibangun warga sebagai benteng terhadap isu penggusuran. Mereka menggunakan dalih bahwa tidak mungkin rumah ibadah dibongkar. Selain itu, keberadaan langgar dan gereja ini menjadi titik perjumpaan warga untuk belajar agama dan pelajaran umum bagi anak-anak. Adanya kedua bangunan ini terbukti efektif hingga saat ini membantu mempertahankan keberadaan kampung dari berbagai ancaman penggusuran.

Walaupun kondisi kampung semakin lama semakin baik, tertata dan rapi, pandangan tiap generasi terhadap kampung ini amat berbeda. Ada yang merasa kampung ini adalah tempat aman untuk bersembunyi dari berbagai peristiwa hidup yang dialami pada masa lalu. Ada yang merasa letak kampung di tengah kota merupakan lokasi strategis untuk mencari kerja dan penghidupan. Namun ada juga yang merasa ingin meninggalkan kampung ini untuk mencari penghidupan yang lebih layak dan mencari peruntungan di luar.

Pada tahun 2016, setelah menjadi juara ketiga lomba kampung tematik, kampung ini perlahan-lahan bertransformasi menjadi kampung yang semakin layak huni. Tingkat kekumuhan telah jauh berkurang dengan membaiknya citra kampung. Selain itu kondisi infrastruktur terlihat semakin lengkap dan tidak terkesan tambal sulam. Setelah diresmikan kampung ini juga sempat menjadi viral karena banyak yang penasaran mengenai kampung tematik di pemakaman.

Saat proses realisasi menjadi kampung tematik memang banyak terjadi persoalan administrasi dan keterbatasan dana. Hal ini sempat menimbulkan kekecewaan karena pembangunan tidak maksimal dan terkesan setengah-setengah. Warga merasa kampungnya hanya dijadikan objek saja dan kampungnya tidak dibimbing serta didukung maksimal untuk menjadi 
kampung tematik yang mandiri. Hal ini membuat saat ini kampung tematik ini sepi pengunjung dan tidak seberhasil kampung tematik lainnya. Kondisi ini membuat warga melalui peran ketua RT terus menerus melakukan pembenahan di sana-sini untuk kampungnya. Menurut mereka jika nantinya tidak bisa menjadi kampung tematik yang mandiri, maka setidaknya pembangunan yang mereka terima akan mereka gunakan untuk peningkatan kualitas layak huni dan taraf kehidupan warga.

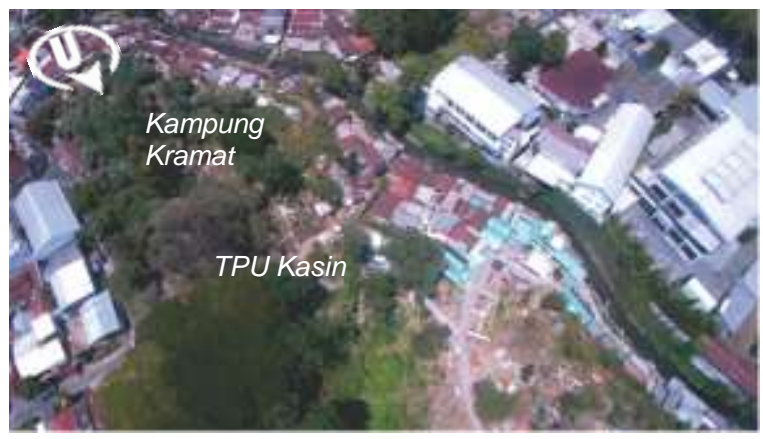

Gambar 6. Foto Kampung Kramat saat ini dari udara

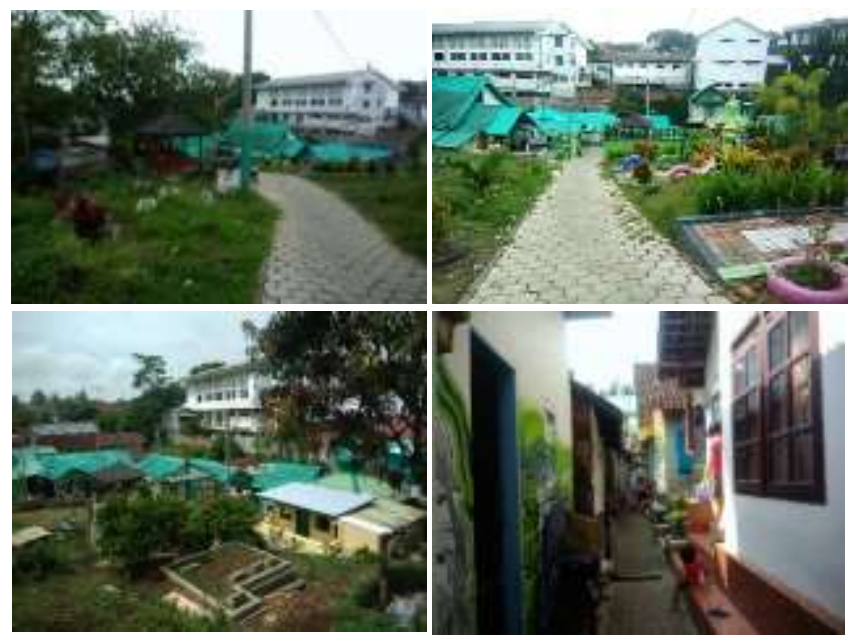

Gambar 5. Foto Kampung Kramat setelah pembangunan kampung tematik

\section{Konsep-Konsep}

Penelitian ini menemukan adanya tiga konsep yang digunakan oleh warga untuk mempertahankan keberadaan dan keberlanjutan kampungnya. Ketiganya dipaparkan sebagai berikut.

\section{a. Pemanfaatan Jejaring Eksternal Kampung}

Dari konsep pemanfaatan jejaring eksternal warga kampung, peneliti memahami bahwa ini merupakan survival strategy yang dilakukan olah warga untuk meningkatkan taraf hidup dan kualitas lingkungan mereka. Jejaring ini dapat diakses karena proses perkenalan-perkenalan yang dialami tokoh tokoh di kampung dan kondisi kontekstual lingkungan perkotaan pada waktu itu.

Memang sejak warga mulai tinggal di lingkungan makam dan saat ini telah berkembang menjadi kampung Kramat, selalu terdapat peran tokoh dan warga kampung dengan jejaring relasi yang dimiliki. Keberadaan tokohtokoh ini mengambil porsi penting dalam mengakses berbagai bantuan dari bermacam-macam lembaga dan instansi serta dalam proses realisasinya di kampung. Jejaring relasi yang dimiliki dari perkenalan tidak terduga maupun direncanakan pada akhirnya membuat bantuan bisa masuk ke kampung sehingga taraf kehidupan kampung dapat semakin membaik. Selain itu, luasnya jejaring yang dimiliki juga menjadi sarana bantuan pada saat kampung mendapatkan permasalahan besar dan genting.

Keberadaan kampung Kramat di tengah konteks perkotaan yang padat dan ramai dengan berbagai aktivitas perdagangan jasa, serta sejarah ruang yang ada juga turut berpengaruh pada kesempatan memperluas jejaring. Kedekatan dengan pusat aktivitas yang ramaipadat ini berimplikasi pada banyaknya lembaga-lembaga keagamaan yang tersebar di sekitar lingkungan Kelurahan Kasin. Hal ini tentunya membuat warga maupun tokoh-tokoh di kampung dapat memperluas jejaring maupun relasi yang terkait dengan bantuan dari lembaga keagamaan

Selain mengandalkan jejaring berbasis keagamaan tersebut, akses terhadap pemangku kebijakan dan pemerintah juga diperlukan oleh warga kampung untuk membentengi diri dari kemungkinan-kemungkinan digusur maupun direlokasi. Dengan kedekatan dan relasi serta jejaring dengan keyperson di pemerintah, informasi terkini mengenai kesempatan pemanfaatan bantuan-bantuan formal dalam berbagai bentuk bisa diakses. Jejaring ini juga memungkinkan lobi-lobi saat ada permasalahan yang menyangkut lingkungan kampung dengan pihak di luar kampung.

Dalam konteks pemanfaatan jejaring ini, tujuan akhir dari memanfaatkan relasi eksternal yang didapat adalah untuk meningkatkan survivability warga kampung dan lingkungannya. Keterbatasan kondisi ekonomi, kondisi sosial-politik serta tara penghidupan warga yang berada di bawah rata-rata memang membutuhkan solusi kreatif kontekstual terhadap kondisi holistik kampung. Oleh karena itu, pemanfaatan jejaring ini secara sadar maupun tidak sadar akan membuat keberadaan kampung dan warganya semakin berlanjut. Tanpa adanya jejaring yang diakses oleh warga, kondisi kampung Kramat tidak akan menjadi seperti sekarang.

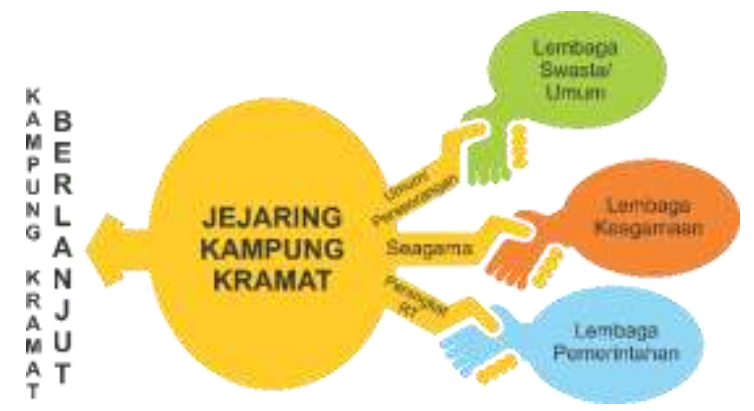

Gambar 7. Konsep pemanfaatan jejaring eksternal kampung 


\section{b. Pergeseran Kampung Pelarian menjadi Kampung Umum}

Keberadaan kampung yang berada di lingkungan pemakaman ini tidak bisa terlepas dari konteks ruang perkotaan yang mengalami dinamika sejak mulai dibangun dari bekas hutan dan tegalan sejak jaman kolonial Belanda [4][5]. Peristiwa-peristiwa personal komunal yang dialami yaitu pergolakan sosial, politik dan ekonomi di masa orde lama, masa G3oS, masa orde baru hingga saat ini membuat warga kampung mengalami berbagai pengalaman ruang selama tinggal. Sehingga pada akhirnya, memang sudah sejak keberadaan kampung mulai terlihat dan dipantau oleh berbagai pihak, warga kampung harus bersusah payah untuk dapat menjauhkan diri dari "ancaman-ancaman" yang membayangi tersebut. Berbagai upaya kemudian dilakukan mulai dari mengusir masyarakat liar di pemakaman, menjalin relasi baik dengan pihak TPU, kelurahan dan lingkungan sekitar, membangun benteng penggusuran yaitu langgar dan gereja serta memilih pekerjaan yang tidak kriminal. Hal ini dilakukan karena warga sangat sadar bahwa sewaktu-waktu Pemerintah Kota dapat mengusir mereka dari tanah pemakaman. Sehingga dapat dipahami bahwa warga harus pandai bersikap baik (mengambil hati) agar mereka masih diperkenankan tinggal di lingkungan kampung untuk waktu yang lama.
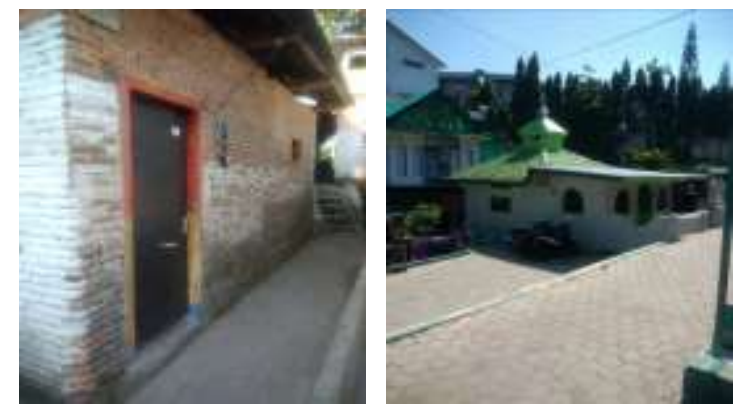

Gambar 8. Foto Gereja dan Langgar di kampung Kramat

Dalam perjalanan kampung hingga saat ini, proses pergeseran kampung menjadi semakin umum, terbuka dan semakin inklusif juga terjadi karena peran tokohtokoh di kampung yang mengakses berbagai lembaga pemberi bantuan dan dukungan Pemerintah. Sedangkan dari perspektif sosial-politik, pilihan Pemerintah untuk tetap mengizinkan warga kampung Kramat tinggal di lingkungan makam dengan memberikan bukti PBB serta KTP beralamatkan Kasin Gang Kramat dengan jelas mengisyaratkan bahwa warga dan lingkungan kampungnya mulai diakui. Selain itu, kondisi infrastruktur dan hunian yang semakin menuju layak huni mengisyaratkan proses pergeseran menuju kampung umum terjadi secara perlahan namun pasti. Puncak dari kejelasan keberadaan kampung terjadi saat kampung diresmikan oleh Abah Anton (Walikota Malang periode 2013-2018) dan menjadi kampung tematik. Hal ini mengisyaratkan bahwa kampung sudah resmi menjadi kampung yang setara dengan kampungkampung lain pada umumnya.

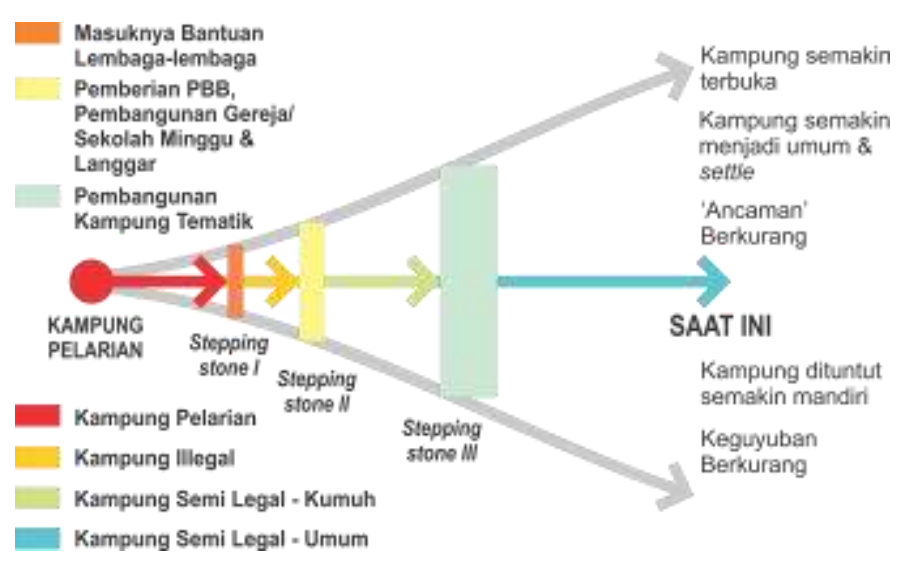

Gambar 9. Konsep pergeseran kampung pelarian menjadi kampung umum

Dari ilustrasi konsep ini, dapat dipahami bahwa saat ini kampung telah berada pada fase keempat tahap pergeseran kampung yaitu menjadi kampung semi-legal, umum. Keberadaan ini merupakan hasil perjalanan panjang dan jalinan dari seluruh pengalaman sejarah ruang, pengalaman sejarah personal-komunal, konteks lingkungan perkotaan dan warga kampung. Dan pada akhirnya eksistensi kampung ini semakin lama semakin menguat dan membesar sehingga saat ini warga dapat berkehidupan dengan tenang dan berkampung seperti pada kampung-kampung pada umumnya (terlepas akankah kampung berlanjut sebagai kampung tematik atau tidak).

c. Pelapisan Generasi dalam Memaknai Kampung

Dalam proses terbentuknya kampung hingga saat ini, keberadaan lintas generasi dan dinamika yang terjadi pada tiap-tiap personal serta komunitas warga di kampung membentuk jalinan dan anyaman lapisan generasi di kampung. Hingga saat ini empat generasi telah ada dan tinggal di kampung. Dari keempat generasi tersebut, generasi yang aktif dan telah turut meletakkan jejak-jejak pengalaman personal-komunal di lingkungan kampung adalah generasi pertama hingga ketiga.

Generasi pertama adalah generasi yang berjuang susah payah dengan segala daya dan upaya untuk tetap bertahan hidup di tengah kondisi sosial-politik-ekonomi yang kacau. Generasi ini adalah generasi yang berjibaku dengan kondisi ekstrim yang ada di lingkungan TPU, mulai dari kondisi fisik yang masih berupa alang-alang dan hutan, hingga konflik-konflik dengan masyarakat liar di sekitar TPU. Rasa aman dan adanya tempat yang dapat digunakan untuk bersembunyi untuk memulai babak kehidupan baru menjadi prioritas utama generasi ini. Segala keterbatasan yang ada juga menjadi pendorong tokoh-tokoh generasi ini untuk turut mengulurkan tangan mencari kesempatan bantuan demi kehidupan di kampung tetap berlanjut.

Berbagai hantaman yang keras dari lingkungan di luar kampung dan latar belakang personal yang 
membebani pada akhirnya membuat generasi ini memiliki pandangan survival is a must. Hal ini kemudian memiliki implikasi bahwa untuk bertahan hidup kesempatan apapun harus diambil untuk memulai penghidupan. Sehingga dapat dipahami bahwa generasi ini sebagian besar bekerja serabutan sebisanya dengan menjadi perawat makam, pemulung, tukang becak hingga kuli angkut di pasar atau tukang parkir.

Generasi kedua adalah generasi yang lahir dan besar di lingkungan pemakaman atau generasi yang datang bersama orang tuanya (generasi pertama) ke lingkungan ini. Generasi ini tumbuh dan berkembang dalam relasi dengan ruang makam dan segala aktivitasnya. Kedekatan dengan lingkungan makam ini membuat mereka tidak merasa canggung maupun takut dengan stigma buruk yang melekat pada kampung di pemakaman yang identik dengan liar, kumuh, dari warga di lingkungan luar kampung. Mereka sudah terbiasa dengan stigma semacam itu karena mereka memang membawa identitas itu bersama mereka.

Selain itu familiaritas yang dimiliki terhadap lingkungan makam dan kondisi pemakaman yang ramai membuat mereka memiliki anggapan bahwa lingkungan ini memiliki nilai ekonomis untuk penghidupan. Hal ini menyebabkan sebagian generasi ini menjadi penggarap makam maupun perawat makam atau pekerja lain yang masih berada di lingkup sekitar makam. Generasi ini juga memanfaatkan letak kampung yang berada di dekat jantung perkotaan kota Malang untuk mencari pekerjaan lain di perkotaan bagi yang tidak ingin bekerja di pemakaman. Pada masa generasi kedua dinamika keluar-masuk warga pendatang maupun pendatang luar mulai terjadi.

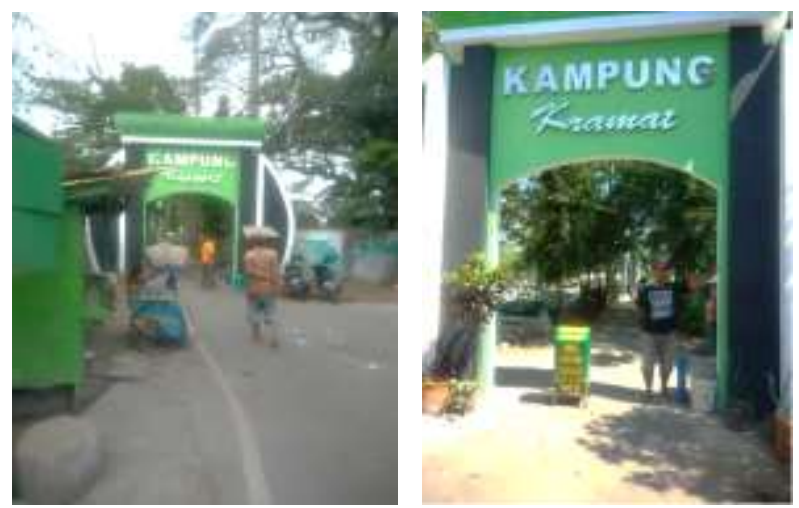

Gambar 1o. Pekerja makam di pintu gerbang kampung Kramat

Sebagai generasi kekinian yang lahir, tumbuh dan besar di lingkungan pemakaman, tinggal di lingkungan kampung kumuh tentunya tidak bisa dibanggakan. Bagi generasi ini meningkatnya kualitas dan citra kampung dibanding generasi sebelum-sebelumnya tidak serta merta membuat generasi ketiga ini tetap ingin tinggal di kampung. Hal ini dikarenakan relasi antar warga dan lingkungannya yang menurut mereka semakin lama semakin tidak guyub akibat pendatang baru dan pendatang luar yang keluar masuk di kampung menjadi salah satu alasan tidak nyaman di kampung.

Pengaruh gengsi jika bekerja di lingkungan pemakaman membuat sebagian generasi ini bekerja jauh dengan konteks pemakaman. Pilihan ini pada akhirnya membuka peluang pergaulan kerja yang lebih luas dengan masyarakat dari lingkungan lain sehingga turut memberi pengaruh terhadap pandangan generasi ketiga untuk tetap tinggal dan menetap di kampung. Hal ini juga menyebabkan sebagian generasi ketiga yang telah bekerja dan berkeluarga ternyata banyak yang mulai mencicil KPR untuk merencanakan pindah dari lingkungan kampung Kramat. Mereka juga menyampaikan kejenuhan terhadap lingkungan kampung yang tidak berkembang bahkan setelah menjadi kampung tematik.

Bagi mereka adanya kemajuan teknologi yang semakin mudah diakses membuat pemikiran generasi ini lebih terbuka sehingga ingin mencari kondisi lingkungan tinggal dan penghidupan yang lebih baik. Hal ini dapat dipahami karena derasnya arus informasi yang mudah diakses oleh generasi ini secara tidak langsung membuat mereka berpikir untuk mencari kehidupan dan penghidupan di luar kampung Kramat yang lebih layak, lebih menjanjikan.

Selain ketiga generasi yang ada kampung Kramat, warga dari luar yang masuk dan berasimilasi dengan warga kampung melalui pernikahan dengan warga asli turut memberikan warna yang bervariasi dalam lapisan generasi di kampung. Masuknya mereka terjadi karena adanya rumah yang kosong akibat dijual/ disewakan oleh penghuni sebelumnya atau ajakan dari generasi asli di kampung untuk tinggal. Warga pendatang ini pada dasarnya tidak memiliki kedekatan akrab dengan lingkungan makam. Hal ini menyebabkan ikatan ruang dan pengalaman personal-komunal terhadap sejarah ruang dan konteks lingkungan kampung lemah. Namun hal ini membuat mereka lebih luwes dan terbuka dalam menerima perubahan-perubahan dari sisi luar kampung dibanding warga asli yang cenderung protektif dan eksklusif. Selain itu pilihan tinggal di kampung di pemakaman ini bagi mereka jauh lebih menjanjikan dibanding dengan tinggal di lingkungan pedesaan. Menurut mereka, kedekatan dengan pusat kota Malang, letak kampung yang strategis, kemudahan mencari pekerjaan harian, serta ketenangan yang didapat di lingkungan pemakaman yang relatif sunyi merupakan situasi yang ideal bagi mereka. Hal inilah yang membuat mereka memilih menetap dan tinggal di kampung Kramat. Walaupun komposisi dan dinamika ini merupakan sesuatu yang tidak dapat ditolak, jumlah pendatang yang semakin banyak dirasa mengurangi keguyuban dan ikatan kekeluargaan warga asli di kampung. 


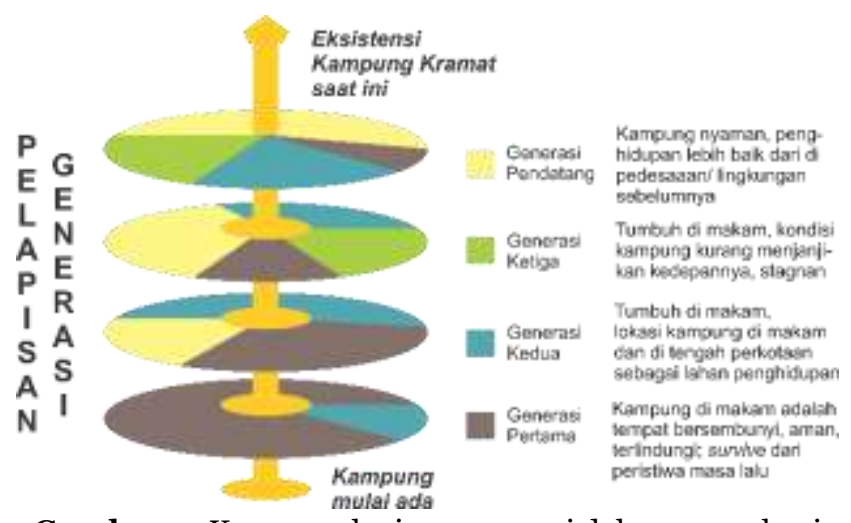

Gambar 9. Konsep pelapisan generasi dalam memaknai kampung

Berbagai lapisan generasi yang telah dipaparkan dengan pandangan yang berbeda dalam memaknai kampung merupakan lapisan unik yang saling terikat kuat dengan konteks lokal kampung ini. Di sisi lain, keberadaan generasi pendatang ini sudah pasti memberikan warna lapisan tersendiri bagi pelapisan generasi yang telah ada sejak 50 tahun lalu. Hal ini dapat dipahami karena keberadaan lapisan-lapisan tersebut akan saling memberikan warna dan "roh kehidupan" pada aktivitas di kampung. Sadar maupun tidak sadar, pilihan warga asli yang terbuka menerima keberadaan dan masuknya warga pendatang membuat kampung ini tetap hidup. Mereka akan berkembang dinamis seturut keberadaan generasi yang ada di dalamnya dan berubahubah komposisinya seiring keberadaan kampung dalam perjalanan bentang waktu. Generasi-generasi inilah yang menjadi penentu arah perkembangan kampung Kramat ke depan.

\section{Abstraksi Konsep}

Dari konsep yang telah dipaparkan sebelumnya, dapat dirumuskan bahwa ketiga konsep tersebut membentuk kesadaran yang ada di kampung Kramat. Kesadaran ini terbentuk dari tiga pilar yang menyokong keberadaan makam dan keberlanjutannya hingga saat ini serta di masa mendatang. Pilar pertama adalah sejarah, pilar kedua adalah tokoh, dan pilar ketiga adalah generasi.

Pilar sejarah adalah kesadaran yang ada dan muncul bersama konteks waktu yang timbul di kampung. Sejarah ruang dan konteks perkotaannya, sejarah personal-komunal dalam dinamika di kampung, serta segala pengalaman yang turut hadir berdampingan dan menyejarah bersama warga merupakan manifestasi kampung; yang jika ditarik ke belakang telah ada sejak keberadaan hunian di lingkungan pemakaman tersebut mulai ada (exist). Pilar kesejarahan ini membentang melintas ruang, waktu dan peristiwa selama lebih dari 50 tahun kampung Kramat telah ada. Mulai dari keberadaan lingkungan awal yang belum dapat disebut kampung dengan ketakutan yang melanda akibat kondisi sosial-politik pada waktu itu, hingga peresmian menjadi kampung tematik yang membuat eksistensi semakin diakui sebagai kampung umum. Ini adalah bentang sejarah yang turut membentuk kampung dan akan turut membentuk kampung ke depannya.

Pilar tokoh adalah kesadaran yang muncul di kampung dalam upaya untuk semakin bertahan hidup (survive) di tengah kondisi kontekstual yang dialami kampung keramat dari waktu ke waktu. Pilar ini tidak lain merupakan perpanjangan tangan dari eksistensi kampung untuk semakin mengamankan diri dan meningkatkan survivability-nya di tengah kondisi ekonomi yang terbatas, kondisi sosial-politik yang dinamis, serta konteks ruang perkotaan yang melingkupi kampung. Keberadaan tokoh-tokoh ini merupakan pilar yang menjulur keluar sekaligus ke menyokong ke dalam dari keberadaan kampung. Sadar maupun tidak sadar, bagi kampung, keberadaan tokoh-tokoh yang dipercayakan ini berperan besar dalam keberlanjutan kampung dan menjadi "semut pekerja" yang mondarmandir memperkuat eksistensi kampungnya dengan berbagai daya dan upaya agar keberadaan kampung Kramat dan keseluruhan isinya dapat terus berlanjut dan survive.

Pilar generasi adalah konsep mengenai keberadaan generasi turun temurun di kampung yang menjadi "roh" dinamika kehidupan kampung serta berpengaruh terhadap keberlanjutannya. Dinamika dan interaksi yang terjadi antar generasi secara sadar maupun tidak sadar memberi isyarat bahwa kampung akan terus "berdenyut" dan tetap ada (exist). Dalam dinamika lintas generasi tersebut, kekayaan pandangan dalam memaknai kampung, kekayaan nilai-nilai (values) yang melekat dalam ruang kampung, serta seluruh pengalaman personal-komunal yang dimiliki warga, pada dasarnya adalah bentuk kedalaman relasi-interaksi proses hidupberkehidupan yang terjadi dalam wadah ruang kampung. Adanya generasi-generasi ini pada akhirnya menyiratkan dinamika kehidupan kampung kota yang ada di atas lingkungan makam ini akan berlanjut keberadaannya. Jika generasi-generasi ini tidak ada lagi di kampung maka bukan tidak mungkin kampung akan berhenti eksistensinya.

Berdasarkan paparan tersebut, jika disusun dalam bentuk visual-konseptual, abstraksi ini berbentuk sebagai berikut.

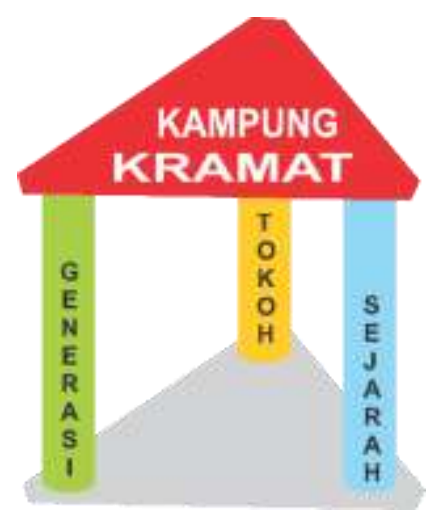

Gambar 1o. Abstraksi Pilar-Pilar Keberadaan dan Keberlanjutan Kampung Kramat 
Dari ilustrasi abstraksi konsep ini, dapat dipahami bahwa keberadaan ketiga pilar ini adalah penopang eksistensi dan keberlanjutan kampung Kramat. Jika salah satu saja pilar ini hilang atau goyah maka keberadaan dan keberlanjutan kampung Kramat terancam tidak ada lagi. Adanya pilar-pilar yang menopang ini merupakan konsep-konsep yang membentuk keberadaan dan keberlangsungan eksistensi Kampung Kramat hingga saat ini.

\section{TEMUAN DAN DISKUSI}

Temuan paper ini yaitu adanya pilar-pilar keberadaan dan keberlanjutan Kampung Kramat. Pilarpilar ini terbentuk dari konsep-konsep meruang serta hidup-berkehidupan warga kampung yang kontekstual dan kompleks. Pilar-pilar ini merupakan abstraksi dari jalinan berbagai pengalaman yang dimiliki oleh warga secara personal-komunal, keberadaan ruang kampungmakam-kota, serta dinamika generasi yang ada di kampung. Contoh dari kampung Kramat ini juga semakin memperkuat konsep yang diutarakan oleh Sudaryono mengenai adanya konsep eksistensi spasial, ketahanan komunitas lokal, dan solusi lokal dalam paradigma lokalisme perencanaan spasial [7]; dalam hal ini adalah mengenai kasus kampung kota.

Dalam kerangka berpikir ruang kampung sebagai suatu bentuk konsep kesadaran meruang, ketiga pilar tersebut merupakan hasil pengejawantahan kesadaran warganya. Hal ini mengarahkan mereka pada pilihan pemanfaatan ruang tertentu. Perjalanan mereka untuk ingin terus survive di tengah pemakaman membuat mereka mengambil cara-cara unik untuk menghindarkan diri dari penggusuran. Salah satu contohnya adalah membangun langgar dan gereja di tengah kampung. Dalam benak mereka tidak pantas bagi masyarakat ketimuran yang beradab untuk menghancurkan/ membongkar rumah ibadah. Hal ini menjadi alasan mereka memilih bangunan agama sebagai benteng penggusuran. Mereka percaya bahwa kampung dapat tetap dipertahankan keberadaan dan keberlanjutannya dengan adanya bangunan tersebut.

Dalam kerangka eksistensi ruang sebagai hasil peristiwa sejarah, temuan ini juga memperkaya pembahasan mengenai tumbuh dan berkembangnya kampung di pemakaman oleh Garr [8] dan Setiawan [9]. Dalam kasusnya di Blimbingsari Yogyakarta, keberadaan kampung di makam Tionghoa terjadi akibat adanya kekosongan lahan di sekitar pemakaman dan persepsi masyarakat Jawa bahwa orang keturunan Tionghoa adalah minoritas. Sentimen ini memunculkan justifikasi bahwa atas nama kebutuhan rumah bagi warga mayoritas, mereka harus mengalah. Sedangkan dalam kasus Kampung Kramat, kampung ini terbentuk karena adanya peristiwa politik tahun 1965 yang meluas hingga kota Malang. Walaupun memiliki lokasi kampung yang mirip yaitu di pemakaman, kedalaman sejarah dan latar belakang memberikan keunikan tersendiri yang jelas berbeda. Pendalaman kasus ini juga mempertegas bahwa konteks kesejarahan kampung membentuk perilaku meruang yang unik dan kontekstual sesuai pengalaman personal-komunal yang dimiliki warganya. Dalam hal ini, keberadaan setting kampung yang terbangun di TPU Kasin merupakan contoh nyata perjalanan ruang yang amat terikat kuat pada sejarah lokal-lokusnya [7].

Dalam konteks mempertahankan eksistensi dan keberlanjutan kampung kota, kampung Kramat adalah contoh nyata relasi yang gigih antara kampung dengan ikatan lingkungan sekitarnya melalui relasi kampungmakam-kota. Hal ini memperkuat pendapat Putra [10] mengenai space relationship dalam konteks survival kampung kota di lingkungan urban serta konteks relasi kampung-makam dalam hal ekonomi dan struktur pembentuk ruang kampungnya oleh Puspitasari [11]. Tarik-ulur relasi ini tidak lain merupakan bentuk simbiosis ruang antara warga kampung dengan lingkungan makam-kota di sekitarnya dalam berbagai aspek kehidupan. Mereka saling berinteraksi dengan kondisi ruang lokal yang mereka diami dan telah mengisi "roh" ruang perkotaan melalui kebisaan mereka mengelola "ruang belakang" perkotaan sebagai tempat tinggal. Oleh karena itu, ruang-ruang terpinggirkan dan tidak terperhatikan yang menjadi basis kehidupan mereka perlu mendapatkan penguatan kembali. Hal ini juga mempertegas signifikansi kampung kota menurut Sihombing [4] sebagai bagian tidak terpisahkan dari kesatuan utuh ruang urban di perkotaaan yang juga amat unik dengan konteks lingkungan lokal informalnya.

Dari diskusi dan temuan yang telah disampaikan, keberadaan dan keberlanjutan Kampung Kramat merupakan suatu representasi pengayaan pengetahuan lokal mengenai kampung kota. Posisi penelitian ini melengkapi kedalaman aspek lokalitas dalam khasanah keilmuan kampung kota. Selain itu, kegigihan warga untuk mempertahankan keberadaan dan keberlanjutan kampungnya dalam relasi kampung-makam-kota merupakan insight yang dapat menjadi bahan refleksi bersama untuk bahan pemberdayaan kampung kota ke depannya.

\section{E. SIMPULAN DAN SARAN}

\section{Simpulan}

Kampung Kramat memiliki konsep-konsep berkampung yang amat kontekstual sejak awal didirikan hingga sekarang telah menjadi kampung tematik. Ketiga konsep (ketokohan, kesejarahan, dan generasi) yang menjadi pilar keberadaan dan keberlanjutan kampung merupakan bentuk manifestasi relasi manusia dengan konteks kampung-makam-kota tempat tinggalnya yang saling teranyam erat. Adanya konsep-konsep ini terbukti telah menopang eksistensi kampung dan keberlanjutannya hingga saat ini. Jika salah satu pilar ini hilang maka bukan tidak mungkin kampung akan terhenti keberadaannya (cease to exist). 


\section{Saran}

Bagi pemerintah, adanya studi ini diharapkan dapat menjadi pertimbangan agar berbagai pihak melakukan kajian mendalam terlebih dahulu sebelum melakukan pengembangan kampung tematik. Adanya konsepkonsep kehidupan warga, filosofi hidup dan pandanganpandangan warga kampung serta histori kampungnya perlu menjadi bahan penting sebelum mengambil bentuk tertentu dalam program pemberdayaan kampung kota melalui konsep kampung tematik. Pengabaian konsep-konsep berkampung yang telah dimiliki dapat menimbulkan kurang efektifnya program pemberdayaan. Selain itu dengan memahami kesadaran mengenai keberadaan kampung, warga bisa lebih diarahkan untuk semakin terlibat dalam aktivitas pemberdayaan. Pada akhirnya rencana dan langkahlangkah selanjutnya dalam pendampingan kampung melalui bentuk kampung tematik dapat lebih tepat sasaran dan lebih berdampak.

Bagi penelitian selanjutnya, konsep-konsep mengenai prospek pengembangan kampung tematik dapat menjadi bahan ulasan yang menarik. Berbagai bentuk kampung yang potensial menjadi kampung tematik tentunya memiliki karakteristik dan latar belakang keunikan yang berbeda-beda. Temuan-temuan yang nantinya ditemukan dapat menjadi salah satu bahan yang memperkaya khasanah pengetahuan mengenai strategi pengembangan dan pemberdayaan kampung tematik di Kota Malang maupun di kota-kota lain di Indonesia.

\section{UCAPAN TERIMA KASIH}

Penulis mengucapkan terima kasih sebesar-besarnya kepada Prof. Ir. Sudaryono, M.Eng, Ph.D yang telah membimbing penulis dalam menyelesaikan penelitian ini. Hasil-hasil temuan dan penggalian konsep-konsep warga Kampung Kramat tidak akan dapat terungkap secara mendalam tanpa arahan dan pemantik dari beliau.

\section{DAFTAR RUJUKAN}

[1] Bramantoro, Toni., (Ed)., Walikota Malang resmikan Kampung Kramat sebagai Destinasi Wisata., diakses Desember 2018 dari http://www.tribunnews.com /travel/2018/o2/14/walikota-malang-resmikankampung-kramat-sebagai-destinasi-wisata, (Artikel 13 Februari 2018).

[2] Rossi, A., The Architecture of The City, MIT Press, Cambridge, 1984.

[3] Lefebvre, Henry., The Production of Space (translated by Donald Nicolson-Smith), Blackwell, Cambridge, 1991.

[4] Sihombing, Anthony., "Kampung Kota: Locality of Places and Spaces", International Research Journal of Architecture and Planning, Vol.1(1), hal. 2-10, Desember 2015.

[5] Handinoto, Peter., Perkembangan Kota Pada Jaman Kolonial 1914-1942, Jurnal DIMENSI 22, h.1-29, September 1996.

[6] Basundoro, Purnawan., Dua Kota Tiga Zaman: Surabaya dan Malang sejak Kolonial sampai Kemerdekaan, Penerbit Ombak, Yogyakarta, 2009.
[7] Sudaryono., "Paradigma Lokalisme Dalam Perencanaan Spasial”, Jurnal Perencanaan Wilayah Dan Kota, Vol 17, No. 1, h. 28-38, Desember 2006.

[8] Garr, D.J., "Expectative Land Right, Housing Consolidation and Cemetery Squatting: Some Perspective from Central Java", World Development, Vol. 24, Issue 12, h. 1925-1933, December 1996.

[9] Setiawan, B., Organized Land Invasion and Social Mobilization in a Chinese Cemetery: Javanese Style, Abstracts Planning for Cities in the Cities in the 21st Century : Opportunities and Challenges, World Planning Schools Congress, Shanghai, China. July 11-15, 2001

[10] Putra, Budi Arlius., "The Survival Phenomenon of Kampung Kuningan Amidst The Development of Mega Kuningan Business-area in Jakarta", International Journal of Scientific \& Engineering Research, Vol 4, Issue 1, h.1-6, January 2013.

[11] Puspitasari, Popi, et.al., Ritual and Space Structure: Pilgrimage and Space Use in Historical Urban Kampung Context of Luar Batang (Jakarta, Indonesia), ASEAN Conference on Environment-Behaviaour Studies, Savoy Homann Bidakara, Bandung Hotel, Bandung, Indonesia, 12-17 June 2011. 